\title{
Figuras del mal gobierno: "españoles soberbiosos e indias putas" en la obra de Guaman Poma de Ayala
}

\author{
Images of Bad Government: "proud Spaniards and Indian whores" in \\ Guaman Poma de Ayala's works
}

\author{
Marcel Velázquez Castro \\ Universidad Nacional Mayor de San Marcos, Lima, Perú \\ Contacto: mvelazquezc@unmsm.edu.pe \\ https://orcid.org/0000-0002-5770-8400
}

\begin{abstract}
Resumen
En la segunda sección de su obra, denominada "Buen gobierno", Guaman Poma nos ofrece algunas de las más detalladas y vívidas descripciones del funcionamiento del poder colonial. Este ensayo revisa dichas interacciones a partir de dos perspectivas complementarias: (i) la inmensa brecha entre el "deber ser" y la acción social frecuente de esas autoridades; (ii) la condena a la violencia ejercida contra los indios, la cual adoptaba las figuras del castigo físico, el robo, la explotación laboral, la violación sexual, la amenaza verbal, entre otras. La explicación de esta violencia como ejercicio del poder colonial se solía representar con dos vicios: codicia y lujuria. A partir de la problemática social que la obra de Guaman Poma revela, me interesa destacar la función que desempeñó la representación del cuerpo de los indios como un espacio en el que se materializaba el poder colonial, así como el ambivalente rol de la sexualidad en dicha dinámica.
\end{abstract}

Palabras claves: Felipe Guaman Poma de Ayala; Cuerpo; Violencia; Vicios; Sexualidad; Poder colonial

\begin{abstract}
In the "Good Government", the second part of his chronicle, Guaman Poma presents some of the most detailed and vivid descriptions of colonial power in the Andes. This essay looks at such descriptions from two points of view: (i) the great gap between what should have been (good behavior) and the frequent social action of authorities related to this, and (ii) the condemnation of violence against the Indians, violence manifested in physicial punishment, theft, labor abuses, rape, verbal threats, among others. The author refers to two vices to explain violence as a consequence of colonial power: greed and lust. Departing from the social problems that Guaman Poma
\end{abstract}


reveals in his chronicle, this essay pays attention to the representation of the Indian body as a place for the execution of colonial power and the ambivalent role of sexuality.

Keywords: Felipe Guaman Poma de Ayala; Body; Violence; Vices; Sexuality; Colonial power

Recibido: 15.10 .19 Aceptado: 07.01.20

En la sección denominada "Buen gobierno", el indio ladino Guaman Poma nos ofrece una de las más detalladas y vívidas descripciones del funcionamiento del poder colonial. No solo revisa el papel de todas las figuras que concentran autoridad política, judicial y religiosa (desde el propio virrey hasta los mandoncillos locales), sino sus prácticas sociales y las complejas interacciones entre ellas. El discurso adopta diversas modalidades expresivas para persuadir al lector, como la narración, argumentación, exhortación, amonestación, imprecación, lamentación, entre otras. Introduce también complejos recursos retóricos como la parodia de voces, diálogos ficcionales e historias particulares ejemplificadoras. Durante toda la extensa presentación sobresalen dos perspectivas complementarias: (i) la inmensa brecha entre el orden ideal y la acción de las autoridades (corregidor, encomendero y cura doctrinero) que crea el caos social, y (ii) la condena a la violencia injustificada ejercida por dichas autoridades contra los indios.

A Guaman Poma no le indigna la violencia en el marco de las guerras, como lo muestran los dibujos de los capitanes incas que aparecen extrayendo ojos con tenazas, cortando el pecho o decapitando a enemigos (pp. 147, 163 y 196) ${ }^{1}$; ni la violencia institucional derivada de un acto de justicia legítimo, como lo evidencian los dibujos donde se observa el castigo por lapidación para la mujer adúltera, el colgamiento de los violadores de los cabellos hasta morir y los garrotazos hasta matar a toda la casta o ayllu de los envenenadores (pp. 308, 310,312 ). Efectivamente, todos ellos constituyen formas de restaurar el orden y la justicia en el período inca. La violencia insoportable para el cronista es la que ocurre fuera de los marcos de la guerra o de la justicia, una violencia aleatoria 
e inmotivada que atenta contra la estabilidad y previsibilidad del orden social. Esta tiene su origen en la voluntad de dominio y control del territorio y de los sujetos andinos por los españoles; adopta, asimismo, múltiples formas: el castigo físico, el robo, la explotación laboral, la violación sexual, los insultos verbales, entre otras. En muchas ocasiones, el cuerpo de los indios se configura como un espacio donde se materializa y se inscribe esta violencia ilegítima que se deriva del poder colonial. La causa de esta violencia se traduce en códigos religiosos y, por consiguiente, posee dos motores principales: codicia y lujuria, pecados capitales según la doctrina cristiana y objetos frecuentes de múltiples anatemas desde el púlpito de los predicadores. La consecuencia de esta violencia acarrea implicaciones políticas y económicas: el mal gobierno y la pérdida de valor material del reino por la disminución de la población india, en palabras del texto: "no multiplica ni multiplicará los indios deste rreyno" (p. 448), lo que provocará menor recaudación del tributo indígena en las arcas reales.

Teniendo en cuenta esta dimensión de la obra de Guaman Poma, analizo a continuación dos problemas asociados con la manifestación de la violencia: (i) la representación de la soberbia en las malas autoridades españolas (corregidores, encomenderos, curas doctrineros), su acción violenta contra los cuerpos de los indios y la función retórica que cumple el virrey Toledo como paradigma de la autoridad soberbiosa; (ii) la representación de la lujuria en el binomio cura violador/indias putas que nos lleva a examinar el papel del cuerpo femenino como valor de cambio y la función que cumple el personaje mítico de Mama Huaco como matriz de la conducta sexual indígena transgresora. La soberbia posee una dimensión religiosa y otra social-cortesana, ambas imbricadas, pero también su predominio es expresión de un "mundo al rreués" o período de caos social andino. Asimismo, la lujuria y la sexualidad interétnica entre el varón colonizador y la mujer colonizada expresan un complejo haz de violencia, deseo y seducción. El despliegue textual de estos vicios descubre los códigos morales cristianos y las racionalidades económicas andinas que se entrelazan en el discurso guamanpomiano. 


\section{La soberbia de las autoridades coloniales españolas y su violencia sobre el cuerpo de los indios}

Según la Nueva corónica, la acción social de los corregidores, encomenderos, curas y otros elementos de la administración colonial indica que no hay respeto ni por Dios ni por el rey. El abuso colonial expresa simultáneamente la falta de justicia y la transgresión religiosa. Por ello, una acusación transversal contra los funcionarios coloniales asume la siguiente formulación: "son tan señores apsolutos con poco temor de Dios y de la justicia. Hazen muy grandes males y daños a los pobres prencipales y a los indios deste rreyno" (p. 493). La primera parte de este enunciado (“son tan señores...") se convierte en una fórmula verbal que se repite y se emplea en innumerables oportunidades. En la misma dirección, se amonesta a dichas autoridades: "Lo que Dios manda, queréys ser más" (p. 439), es decir, los funcionarios coloniales son figuras descontroladas que atentan contra el orden social establecido por la divinidad.

El concepto de "buen gobierno" es un ideal y un principio trascendente que constituye el orden político regido por valores morales religiosos, que aparece situado tanto en el pasado como en el futuro. De este modo, el relato en la crónica guamanpomiana se construye desde la experiencia del desastre, pero articula un campo de deseo formado por una compleja urdimbre de memoria y utopía. Guaman Poma expresa reiteradamente que los corregidores son enemigos de los caciques principales y de los indios. El texto lo expresa dramáticamente: "comiendo su sudor de ellos y sus trabajos" (p. 494); de este modo, el orden colonial se alimenta de la población india, explícitamente de su fuerza física laboral. Hay un pacto ominoso entre encomendero y corregidor: "entre los dos desuella a los pobres indios deste rreyno" (p. 496). La elección del verbo no es casual, pues refuerza el sentido profundamente violento de la explotación y remite al cuerpo donde se inflige el poder. Aunque la frase es hiperbólica, la acción de "arrancar la piel" a los indios sometidos los coloca en un grado de infrahumanidad manifiesto. Si el "hombre vestido" de acuerdo con su rango y filiación étnica constituye el código convencional del texto (tanto en la escritura como en los dibujos), el "hombre desnudo" conforma un ser disminuido social y culturalmente; así, el "hombre desollado" ocupa un lugar más abajo en la escala de la deshumanización. 
El autor de la Nueva corónica establece una compleja gradación social entre los cuerpos castigados en sus dibujos. En el punto más alto de la escala se ubica el castigo al cacique cristiano o al indio ladino principal que siempre aparece individualizado, vestido y sin sufrir marcas del látigo en su cuerpo. Ejemplo de ello, las imágenes de Cristóbal León en el cepo (p. 498, figura 1; p. 500), o el caso del cacique principal don Juan Cayanchire colgado, pero con sus vestimentas y la infaltable cruz entre las manos (p. 571). Incluso entre ellos, la diferencia radica en que el primero aparece calzado y vestido más lujosamente. En el otro extremo se encuentra el cuerpo anónimo, el cuerpo indio sin nombre y que aparece en muchos casos desnudo y con las marcas del látigo en toda la piel y en algunas ocasiones con el sexo visible (p. 503, figura 2). Probablemente en contra de lo buscado por el autor, los cuerpos anónimos y lacerados poseen mayor valor en tanto nuda vida (mera potencia) de interpelación, que los cuerpos vejados y vestidos.
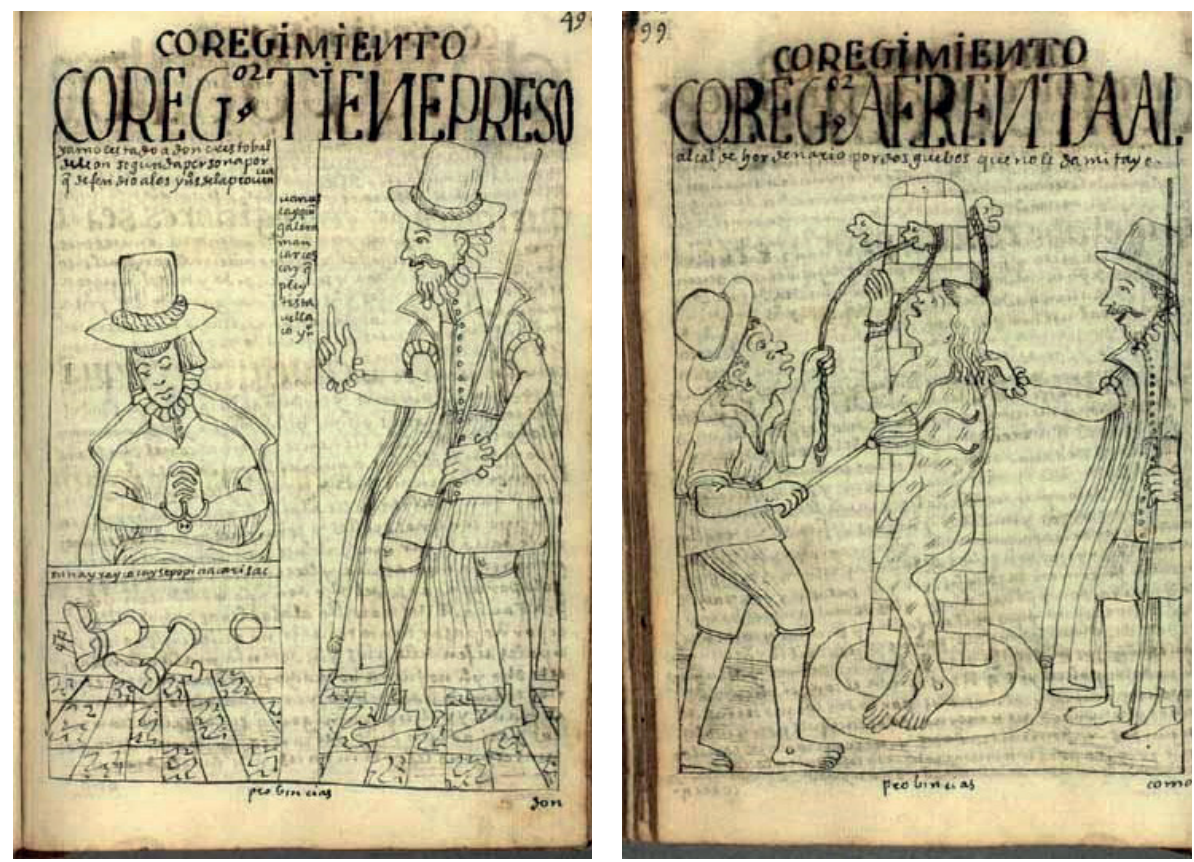

Figuras 1 y 2. Nueva corónica y buen gobierno, p. 498 y p. 503. Biblioteca Real de Copenhague, Dinamarca. 
En cuanto a los que castigan, ¿quiénes son los personajes coloniales que golpean el cuerpo del indio? La responsabilidad de los corregidores y encomenderos aparece mediada porque, cuando se representa el acto mismo de la ejecución de los latigazos, quienes actúan como verdugos son los indios o negros dependientes de dichas autoridades. Una interesante excepción a esta mediación es la figura del cura que sí puede flagelar directamente al cuerpo del varón desnudo (p. 596) o las nalgas del niño semidesnudo (p. 599). El cura encargado del cuidado de las almas de los indios tiene, incluso en el castigo, un acceso privilegiado al cuerpo desnudo de los indios.

Ante este sistema de explotación con múltiples rostros, una posibilidad de resistencia es la del indio ladino que conoce la escritura y, de este modo, enfrenta y denuncia a las autoridades corruptas mediante las propias armas legales que el sistema de dominación pone a su alcance. No todos los indios ladinos asumen esta tarea de resistencia, pues como lo prueba la historia de Cristóbal León, la respuesta contra estos defensores de indios es feroz y ellos terminan vejados, castigados físicamente y hasta muertos por las autoridades locales. En consecuencia, no sorprende que haya otros indios ladinos que quieran ser lengua del corregidor, del juez o de los encomenderos para robar a los pobres indios sus haciendas. Por otro lado, los abusos de los encomenderos contra los indios provocan que estos

[...] no quieren seruir a Dios ni a su Magestad y se ausentan y se están en las punas, estancias y chacharas [sementera] y guaycos [quebrada] metidos. Y ancí no se confiesan ni uiene a la dotrina ni a misa ni le conosen el padre ni el corregidor ni cacique prencipal ni obedese a sus alcaldes y caciques prencipales. Y comen carne cruda y buelbe a su antigua ydúlatra ni quieren serbir a su Magestad. (p. 570)

Los indios escapan de las malas autoridades coloniales, pero con la huída también se sustraen de toda forma de organización social, con consecuencias devastadoras: enfrentan una regresión hacia un período no-cristiano, definido por la ausencia de orden ya que no respetan ni a sus propias autoridades locales. De aquí salen las referencias a la deshumanización del indio que linda con el canibalismo y el retorno de las antiguas prácticas religiosas idolátricas como signos extremos de esa degradación social. Para Guaman Poma era muy importante trazar una 
relación causal entre la acción de las malas autoridades coloniales y la pérdida de legitimidad de las autoridades locales indígenas, pues el fortalecimiento de estas últimas era una de las premisas para el anhelado "buen gobierno" en las colonias.

Un caso extremo y singular de este sistema de dominación colonial es la figura del minero denominado en un dibujo sobre el "corregidor de minas". Asociado al poder económico, el corregidor de minas empleaba una gran fuerza laboral indígena en condiciones extremas de explotación. Los tormentos de los mineros contra los indios son descritos así:

Cuelga de los pies al cacique prencipal y a los demás le asota sobre encima de un carnero y a los demás le ata desnudo en cueros en el rrollo y lo castiga y trisquila. Y a los demás le tiene en la cárzel pública preso en el sepo con grillos cin dalle de comer ni agua [...] se an muerto afrentados y no ay rremedio. (p. 530)

El dibujo que precede a la descripción es harto elocuente (p. 529) de las diversas modalidades de castigo que imponen los mineros, "señores apsulutos que no temen a Dios ni a la justicia" (p. 530, figura 3):

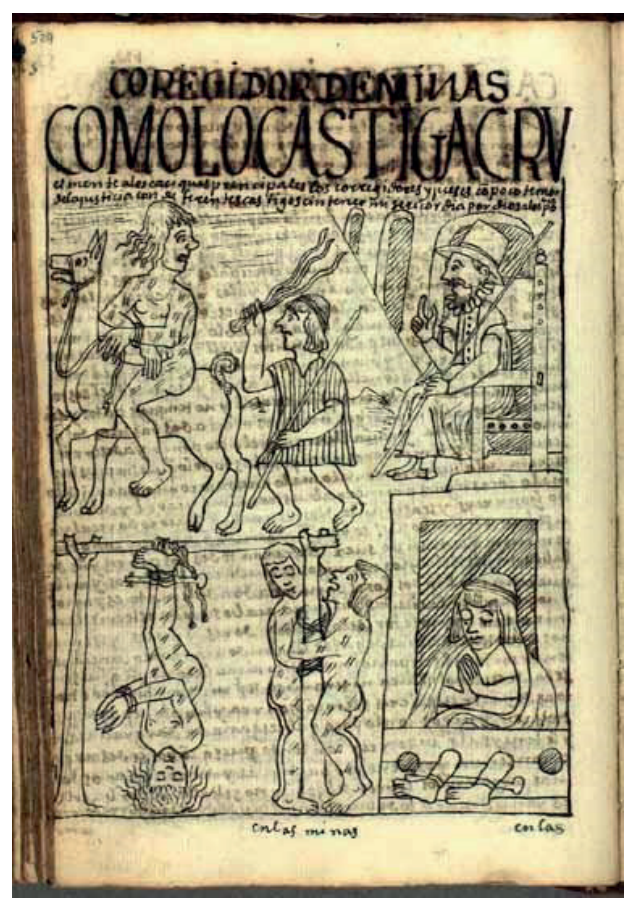

Figura 3. Nueva corónica y buen gobierno (1615), p. 529. Biblioteca Real de Copenhague, Dinamarca. 
Esta impunidad se sostiene porque los corregidores de minas actúan en zonas inaccesibles al control virreinal y por sus alianzas mediante el cohecho con las autoridades coloniales (corregidor, gobernador, juez, alcalde mayor). Ante el despliegue de este poder fáctico sin límites, la institución del Protector de Indios no solo está de más, sino que eventualmente se alía con los explotadores.

Los mineros no pagaban dinero por el trabajo indígena y exigían a los nativos otras tareas además del trabajo en la mina como cuidar el ganado, tejer, encargarse de la cocina, o servirlos. El minero también violaba a las mujeres indígenas y azotaba sin razón a los indios, a quienes desnudaba primero: "y la güergüensa fuera; le castiga como a niño en las nalgas y otros le apalea como animal cauallo, como a su negro esclabo. Y les haze otros muy muchos agrauios que por pruligidad no se escriue" (p. 531). Los textos citados son elocuentes, pero quiero enfatizar su doble dimensión física y moral. La asociación metonímica por contigüidad con ciertos animales (carnero ${ }^{2}$ y caballo) y el empleo de la polisémica voz "trasquilar" para referirse a cortar el cabello constituyen evidentes procesos de deshumanización y desvalorización social, y una emasculación simbólica, pues el cabello largo era un signo de afirmación de la identidad indígena. Por otro lado, en la cita mencionada arriba, la serie de símiles para intentar representar la intensidad del castigo es altamente significativa, pues el cuerpo del indio aparece completamente desnudo, exhibiendo los genitales y tratado consecutivamente como un niño (aquí cabe recordar que niño equivale a sujeto con una racionalidad no desarrollada plenamente) cuyas nalgas son un territorio donde el poder se inscribe. Se establecen paralelos con el tratamiento de un animal que pertenece por antonomasia al español, el caballo, y luego con el esclavo, otra propiedad sobre la cual el amo puede ejercer su dominio mediante golpes. Así, el indio castigado ocupa los límites de la humanidad, las fronteras del ser humano, como el niño y el esclavo.

Rolena Adorno (1992 [1989]), ha señalado que el eslabón entre la lectura social del mundo-al-revés y la dimensión cósmica de la ausencia de Dios se articulaban mediante "la soberbia, el orgullo excesivo y la arrogancia, es decir, el pecado del mismo Lucifer" (p. 216). Este representa "la autoridad erróneamente usurpada $\mathrm{y}$, consecuentemente, dramáticamente castigada” $\mathrm{y}$, sin 
embargo, concluye la investigadora: "en el mundo iconográfico de Guaman Poma, tales manifestaciones de soberbia luciferina permanecen sin castigo" (Adorno, 1992 [1989], p. 217). A diferencia de esta interpretación, planteo que hay una imbricación entre la lógica teológico-religiosa de la soberbia y la sociabilidad cortesana y que sí hay un castigo ejemplar — narrativo e iconográfico — a la figura arquetípica de la autoridad soberbiosa: el virrey Toledo.

\section{El virrey Toledo como arquetipo de la autoridad española soberbiosa}

Norbert Elias (1996 [1969]) plantea que "la grandeza y el esplendor no son expresión primaria de la riqueza, sino del rango y de la posición" (p. 75). En esa línea, en toda sociedad cortesana hay una clara oposición entre los que ejercen profesión u oficio y aquellos que poseen un estado (eclesiástico, oficial del rey, entre otros). Guaman Poma asume y conoce las reglas de la sociabilidad cortesana; por ello, evoca con nostalgia que antes de los tiempos de Toledo, "no auía dones ni doñas ni mundo al rreués" (p. 450). En contraposición, en el presente en que Guaman Poma escribe: "Pulperos, sapateros, xastres, olleros se llama dones y doñas y lesenciados, dotores" (p. 450). Es decir, las personas que ejercen oficios manuales pretenden ser tratadas como personas con un rango social que no les pertenece. En este discurso se entrelazan imágenes propias de la transgresión de los códigos de la sociedad cortesana y el desorden propio de un mundo al revés, un pachacuti andino que en su propia descomposición anuncia el nuevo orden colonial anhelado.

Asimismo, los miembros plenos de la sociedad cortesana siempre llevan una vida pública en contraposición a las vidas particulares de los otros (Elias, 1996 [1969], pp. 76-77). El virreinato del Perú constituía una sociedad cortesana que giraba alrededor de la figura del virrey y, en segunda instancia, de la del Arzobispo. Por lo tanto, todo acto de los miembros más altos de esa sociedad tenía un carácter público, principalmente durante el nacimiento, bautismo, matrimonio y muerte, ya que estos momentos vitales se intersecan con valores y expectativas del ámbito religioso. En el marco de estos presupuestos conceptuales, el relato más desarrollado sobre el virrey Toledo adquiere gran relevancia sobre el conjunto del texto, pues constituye una narración sobre la transgresión de las reglas cortesanas 
y la sanción a esa violación por uno de los garantes del orden político-justiciero, el rey español. Además, la escena de la muerte en el espacio íntimo y privado adquiere una gran significación pública.

En la historia que plantea Guaman Poma, la profunda animadversión de Toledo hacia Tupac Amaru Inca surge porque cuando este último "le enbió a llamar.Dixo que no quería yr a un mayordomo de un señor Ynga como él” (p. 452). El inca desprecia la invitación de Toledo ya que este no tiene la calidad ni la autoridad para convocarlo y tener un diálogo horizontal con él. Nótese cómo se califica con la voz "mayordomo" la función del virrey, un vocablo que también alude al jefe de la servidumbre de la casa y al sirviente principal, en otras palabras, a un sujeto cuya función es asistir a otro y que carece de poder y autonomía propios. El rechazo de Tupac Amaru es su perdición, pues Toledo no va a perdonarlo jamás y, por ello, ordenará más adelante su ejecución. La muerte del último inca de Vilcabamba puede ser leída entonces como una restitución del honor mancillado del virrey, ya que al ordenar su muerte Toledo expresa que él tiene mayor poder fáctico que el inca derrotado.

No ser tratado de acuerdo con la posición que uno ocupa en el orden social simbólico constituye la mayor ofensa posible para un cortesano o funcionario real. Por ello, la profunda relevancia y vinculación simétrica que adquieren tanto la ofensa de Tupac Amaru Inca como el posterior desaire del rey español. En la historia que continúa después del ajusticiamiento del inca, el ahora exvirrey viaja a Castilla y desea rendir pleitesía al rey Felipe II. Sin embargo, recibe el mayor castigo posible para un representante de la corona cuando el mismo rey se niega a verlo: este segundo desaire de autoridad regia que sufre Toledo (un cortesano o un montero de cámara le comunica la voluntad del rey de no recibirlo) no puede dejarlo indemne:

Y queriendo entrar a bezar las manos de su Magestad al señor y rrey don Phelipe, segundo deste nombre, el montero de cámara no le dio lugar ni le dejó entrar ni se le dio lisencia para ello. Con este pesadumbre, se fue a su casa y no comió y se asentó en una cilla. Asentado, se murió uentestates y despidió desta uida. Y acabó su uida sentiéndose del dolor de no uer la cara de su rrey y señor. (p. 461) 
El dolor que mata a Toledo proviene de la ausencia de reconocimiento del monarca español ante los "males" realizados en tierras peruanas: aquí confluyen la lógica cortesana y la doctrina cristiana de la expiación de los pecados. Adicionalmente, el texto remarca que el rey decide no recibir a Toledo porque este ordenó la muerte del inca: esta argumentación traza un reconocimiento de la legitimidad del poder del último inca ${ }^{3}$ y libera de toda responsabilidad al monarca, pues este no le había dado licencia al virrey ni había autorizado la ejecución del inca. En las jerarquías políticas del mundo medieval, solo un rey podía matar a otro rey; de allí el carácter criminal de la decisión y acciones de Toledo.

Finalmente, el exvirrey muere en un espacio doméstico y sentado en una silla casera (p. 460), en un mueble sin autoridad ya que no se trata ni de un trono ni de un solio:

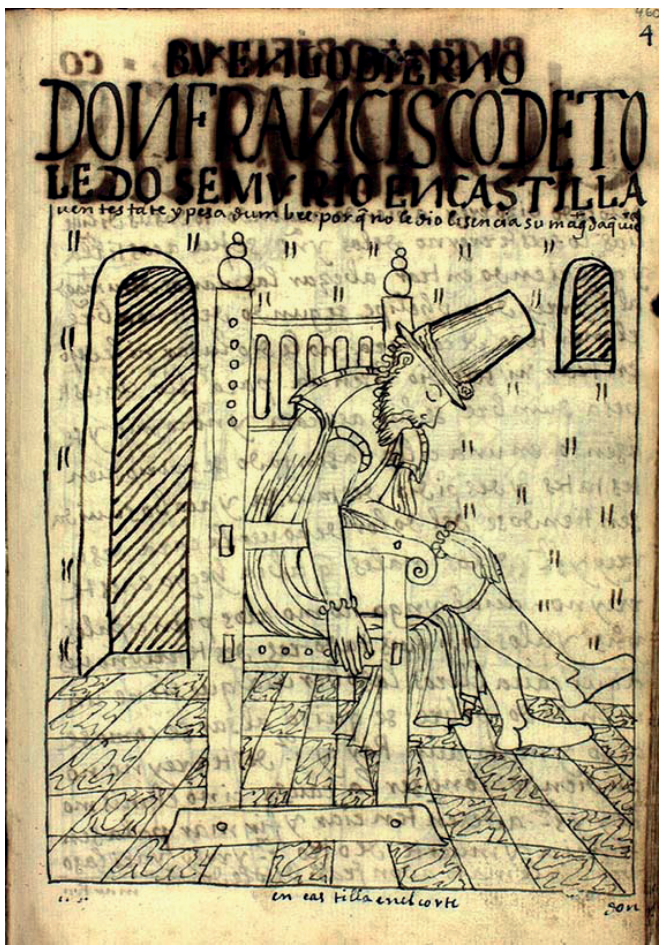

Figura 4. Nueva corónica y buen gobierno (1615), p. 460. Biblioteca Real de Copenhague, Dinamarca. 
En muchos dibujos, las figuras de poder (corregidores, encomenderos, mineros, curas u otras) están sentadas en una silla (idéntica gráficamente a la de Toledo), pero su poder se establece figurativamente con su posición erguida y la firmeza con que están puestos sus pies sobre la tierra. En el caso del virrey en desgracia, su cabeza y su columna aparecen inclinadas; se trata de un cuerpo doblegado, pero además sus piernas no poseen ya firmeza y cuelgan, como las de los ahorcados en otros dibujos, de forma disonante sobre el enlozado. De este modo, el autor "castiga" narrativa y figurativamente al virrey Toledo, la figura arquetípica de la autoridad soberbiosa en la crónica de Guaman Poma.

Este sofisticado manejo de los principios de la sociedad cortesana produce significados tanto en las narraciones como en la iconografía del texto y ratifica su conocido carácter transcultural. Sin embargo, la lógica cortesana no actúa independientemente y se imbrica constantemente con los sentidos religiosos, mediante la historia de Lucifer y la serie de los pecados capitales:

Pregunta, cristiano, quién es el enemigo. El enemigo es la soberbia. No ay cosa oy en el mundo ni en el cielo tan mal que el primer pecado que le acometió a Dios. Fue la soberuia daquel tan lindo y hermoso y de toda sus secguases. [...] Agora, conzedera daquel señor don Francisco de Toledo, bizorrey, que quizo ser más que rrey con la soberuia, ciendo su bizorrey. (p. 950)

La primacía de la soberbia entre los pecados capitales concuerda con lo sostenido por la tomística medieval, como lo planteó fray Luis de Granada, fuente relevante de Guaman Poma: "todos los pecados [...] originalmente nacen del amor propio, porque todos ellos se cometen por codicia de algún bien particular que este amor propio nos hace desear" (1950 [1567], p. 665). La palabra "soberbia", con todas las dimensiones semánticas (cosmogónicas, religiosas, cortesanas) que actualiza, y el adjetivo descalificador "soberbioso" van a ser empleados más de una vez para explicar la conducta y el trágico fin del virrey. La propia conducta negativa, la acción pecadora solo puede conducir a la destrucción del actor. En términos religiosos, el pecado mata al pecador.

La valoración del virrey Toledo dista de ser unívoca y a lo largo de la 
Nueva corónica hay numerosas menciones a su labor administrativa. En esa faceta se reconoce el valor de muchas de sus ordenanzas, incluso algunas inspiradas en el pasado prehispánico ${ }^{4}$; otras novedosas y provechosas ${ }^{5}$, aunque no se cumplen. No obstante, también se señala con claridad el principal error administrativo del virrey: "Después de auerse hordenado los dichos corregidores por don Francisco de Toledo, bizorrey deste rreyno, a rresultado muy grandes daños en estos rreynos del Pirú" (p. 493). El corregidor desempeñaba funciones políticas y judiciales y recolectaba con ayuda de los caciques el tributo indígena; por ello, denuncia Guaman Poma que Toledo "mandó despoblar y rreducir de los pueblos deste rreyno. Desde entonses se a muerto y se ua acauando los indios" (p. 965).

Por otro lado, se reconoce que el gobierno de este virrey marca el final de la denominada "edad dorada" de los padres doctrineros. Durante las primeras décadas después de la conquista, ellos "eran rreys y comenderos, corregidores y caciques prencipales y alcaldes, mandoncillos y era otro Ynga" (p. 598); Toledo acabó en parte con esa época de dominio y abuso sin límites de los padres. Sin embargo, sus buenas disposiciones no se cumplen, como dice un español en un diálogo ficcional: "las hordenansas del señor don Francisco de Toledo y de los demás bizorreys son buenas para yyndios [sic], que no para españoles. Que las hordenansas y leys están en Castilla de los españoles. Somos libres" (p. 1116). La ley está en otra parte, lejos de las prácticas sociales de las autoridades locales. En el capítulo de las "consideraciones" de la sección del "Buen gobierno", se observa con mayor claridad esta ambivalencia, las referencias al virrey se hacen más frecuentes y complejas. A partir de una reflexión teológica sobre la identidad entre los pobres y los pecadores y la misericordia divina por ellos, se desliza el texto hacia la reiterada acusación contra Toledo: "degolla al rrey Ynga. Ciendo un pobre soldado, mata al rrey por su soberuia" (p. 948). Este leitmotiv de la obra se enriquece en dicho fragmento con otros actos de injusticia, como la referencia al ajusticiamiento del corregidor García de Solís Portocarrero en Huamanga o el destierro del príncipe Melchor Carlos Inga, ambos víctimas "sin culpa" de Toledo. 
Una consideración sobre la abundancia en el virreinato de falsos caballeros (llamados "caballeros chanflones" por Caviedes pocas décadas después) permite afirmar la necesidad de honrar al hombre de sangre y linaje por más pobre que sea. Esta argumentación sobre el valor social del ser se desliza inmediatamente hacia una advertencia práctica al "soberbioso cristiano" para que no sea como Toledo,

[...] que sentenció a degollar al rrey ynfante Topa Amaro Ynga, que no pudo según derecho de justicia azeptar esta sentencia [...] antes hincado de rrodilla le deue dar agua, pan o manos y hazello lauarse. Pero tenelle preso hasta entretanto que lo entriegue a su Magestad, dándole paxes y maestresala y alementos y mucha honrra. (p. 951)

La argumentación vuelve a expresar una lógica cortesana en la que Toledo se encuentra subordinado por su linaje y su posición político-social a servir al rey inca $y$, aunque puede hacerlo prisionero, debe siempre tratarlo como a una autoridad superior y con todos los miramientos de un cortesano hacia un rey. En una cita posterior, se reconocen los méritos administrativos del virrey y la utilidad de sus ordenanzas, pero se narra un nuevo relato de su muerte que adquiere una peculiar intensidad dramática por la interpelación directa que asume:

¡o, don Francisco de Toledo, teniendo tanto auilidad y tratado de las hordenansas, que quicistes ser más que rrey y hicistes justicia al rrey del Pirú! Ci entonses su Magestad enbiara un jues que fuera degollado en el mismo tablado, pero no quiso. Como fue tan gran cristiano el rrey, lo dexó por sus pecados. Y por el castigo de la soberbia se degolló el mismo don Francisco de Toledo. Dios saue adónde estás. (p. 951)

Aquí se enuncia claramente la causa de su perdición: él quiso ser más de lo que socialmente le correspondía. Su legítimo castigo era sufrir la pena capital, pero ¿por qué el degollamiento? Esta sanción con evidentes resonancias bíblicas implica cortar el cuello, someter la cabeza, doblegar físicamente al cuerpo que se ha alzado. Cabe recordar que desde la tradición medieval, el ahorcamiento era para gente común y la decapitación, privilegio de los nobles y principales ${ }^{6}$. En la cita anterior, el rey español decide no castigarlo, ejerce su derecho regio del perdón y de la piedad, ya que como "gran cristiano" perdona al pecador, pero 
como no puede haber pecado grave sin castigo, es el propio pecador soberbioso el que debe castigarse mediante el suicidio, y así — según el texto— se autodegolló. De este modo, su sanción es especular a su delito, un ojo por ojo con resonancias vetotestamentarias y propia de la lógica del castigo medieval. No se trata solo de una muerte física, sino de una desaparición mayor pues ahora solamente Dios puede conocer el espacio moral que ocupa el virrey y su legado.

A diferencia del virrey Toledo, que en los distintos relatos sobre su muerte recibe siempre una sanción ejemplar en el relato discursivo y en la iconografía - por lo que, en consecuencia, funciona como amenaza potencial para las autoridades del mal gobierno-, los padres doctrineros, figuras centrales en la reproducción del caos del presente, no reciben castigo alguno, pese a que a la soberbia suman la lujuria.

\section{Los padres doctrineros: soberbia y lujuria}

La violación de la mujer andina por parte de las figuras masculinas de poder remite a una práctica social extendida y repetida incesantemente desde los primeros tiempos de la colonia. Era un secreto a voces que formalizaba la dominación racial/sexual: los varones de los grupos dominantes y, en particular, sus figuras de autoridad disponían libremente del cuerpo de las mujeres en posiciones subalternas y así revalidaban su poder sobre los indios varones. Finalmente, todo un sistema construido sobre la explotación parece condensarse en la violencia sexual contra la mujer india, uno de los últimos eslabones (por criterios étnicos y de género) de la cadena de dominación social.

En este ámbito, la figura más sorprendente es la de los padres doctrineros, los curas encargados de enseñar la doctrina en los pueblos de indios. Ellos cometen una múltiple transgresión: a los votos de castidad, a la tarea de enseñar la doctrina y a la de predicar el evangelio con su propia vida, acusa el texto: "se uan a la cudicia de la plata y rropa y cosas del mundo y pecados de la carne y de apetitos y daños que no se escriue" (p. 576); "[t]eniendo una dozena de hijos, ¿cómo puede dar buen egenplo a los indios deste rreyno?” (p. 576). 
Estos curas que deberían ser los agentes de la salvación religiosa de los indios se convierten en emblema condensado de los tres grandes enemigos del alma: mundo, demonio y carne.

Los curas aprovechan sus obligaciones religiosas, propias de la evangelización, para desvirtuarlas y obtener ventajas económicas y sexuales de los indios. Así, por ejemplo, utilizan la fuerza laboral de la mujer indígena para tejer y luego comercian esos productos sin contraprestación alguna para la trabajadora (p. 576) o emplean la confesión para despojar a los indios de sus bienes: "que no le quite a los yndios sus haziendas, deziendo que en la confición le dixo" (p. 674). Como ya se observó, existe una correlación entre la acción de los curas doctrineros y el cuerpo de los indios, pero no solo en la esfera del deseo sexual, sino también en la del castigo corporal. Aunque la Nueva corónica contiene muchos ejemplos de violencia extrema, uno de los más terribles es la historia del padre Juan Bautista Alvadán, del pueblo de San Cristóbal de Pampachire. Se narra en aquella que ante la negativa del indio Diego Caruas de entregarle un carnero,

[...] le puso en una aspa esponxa como de San Andrés. Le puso en cueros amarrado, comensóle a quemar con candela de sebo, meter fuego en el culo y en la güergüenza, ensendido muchas candelas y brealle. Y le abría el culo con las manos. (p. 580)

Se trata de una crucifixión en una cruz en aspa y una tortura que posee evidentes connotaciones sexuales; ya no se trata solamente de exponer las "vergüenzas", sino de destruirlas mediante el fuego. Posteriormente, el texto narra que una india soltera se quejaba de este cura detallando los vejámenes sexuales que sufría porque este la "desnudaua y le miraua el culo y el coño y le metía los dedos y en el culo le daua quatro asoticos; cada mañana le hacía a todas las solteras" (p. 580). Este cura, obsesionado con el denominado "ojo de Dios", combinaba castigo y placer sexual mediante prácticas sádicas y voyerismo. Aunque es un caso excepcional por su intensidad, traza con precisión el muy común recorrido violento desde el poder colonial hasta el sexo y las partes más íntimas del cuerpo del colonizado.

¿Cómo enfrentar los vejámenes de los curas? Nuevamente, el aprendizaje 
de la lectoescritura se instaura como un mecanismo de defensa por los indios y así se explica que los padres doctrineros:

[...] enpide a que no sepa leer ni escriuir ni gusta que ayga maystro de escuela porque no sepan pleytos y hordenansas y serbicio de Dios nuestro señor y de su Magestad. Lo haze para que no lo aciente sus bellaquerías y maldades y rrobos. (p. 604)

Además, los padres "no concientan que ayga escuela en este rreyno, cino antes se huelga que sean bozales, ydúlatras por rroballe y quitalle a los pobres" (p. 637). Este es un argumento que recorre todo el texto: la escritura de sujetos andinos como mecanismo de resistencia y denuncia; nótese que se trata de una competencia, principalmente, para actuar en el ámbito legal ${ }^{7}$. Ante esto, los padres prefieren mantener a los indios en el desconocimiento de la lengua española, de la letra y del evangelio para mantenerlos fuera del orden simbólico hegemónico y legitimar mediante esta exclusión despojos y latrocinios. En síntesis, para el autor, la plena subjetividad andina, pilar del deseado buen gobierno, implica la lectoescritura de los indios. Por otro lado, la acción de los curas doctrineros constituye una competencia asimétrica en la economía de la sexualidad andina; ellos monopolizaban las mujeres y, como el texto clama: "y no le dexa soltera al yndio" (p. 598 [612]). Cuando se les enrostra a los padres su conducta, estos se enojan porque ellos empleaban a sus mujeres en diversas tareas:

[...] lo primero, por tenella por su amanseba; el segundo, por tenella por alcagüeta; el tersero, por tenella para que le lleue chismes, mentiras; el quarto, por tenella en la cocina y con color della, depocitalla a las yndias solteras o amansebadas para fornicalla y hazella trauajar cin pagalle; el quinto, por tenella para rrescates y pulpera, chichera, panadera y haze hilar, texer rropa y gana plata; el sesto, por estar amansebada con la hija de la cosenera o con su ermana o con su criada o sobrinas para rreseruar y euitar pleytos e quexas. (pp. 611-612)

Como se observa en la cita, no se trata solo de lujuria desbocada, sino de una variada red de funciones, mediaciones y tareas de toda índole. En esta situación, no es despreciable la fuerza de trabajo y las tareas económicoproductivas que desempeñan las mujeres indias en la casa del cura doctrinero. En una economía campesina, la mujer es valiosa fuerza laboral tanto en el ámbito 
doméstico como en la agricultura y otros espacios. Por ello, las quejas de Guaman Poma, en clave andina, también remarcan la sustracción ilegítima de los curas doctrineros de esa fuerza laboral.

El texto también demanda innumerables veces que los curas no adoctrinen religiosamente a las jóvenes indias en sus propias casas, sino que enseñen el evangelio a los niños entre los cinco y siete años. Pues el contacto físico a solas con las mujeres enciende el deseo. Esta era una concepción sólidamente arraigada en la visión cristiana, como lo ratifica fray Luis de Granada:

Nunca te pongas a tratar con mujer sin testigos, porque estar solo incita y convida a todos los males. [...] Huye, pues, toda sospechosa compañía de mujeres, porque verlas daña los corazones; oírlas, los atrae; hablarle, los inflama; tocarlas, los estimula, y, finalmente, todo lo de ellas es lazo para los que tratan con ellas. (1950 [1567], pp. 692-693)

Cabe añadir aquí la figura de la barragana del cura, muy conocida a fines de la España medieval y durante el Renacimiento, como lo atestigua la literatura de la época ${ }^{8}$. Esta práctica social se reproduce en tierras indianas:

[...] tienen unas yndias en las cocinas o fuera de ella que le cirue como su muger casada y otras por manseba y en ellas tiene beynte hijos, público y notorio. $\mathrm{Y}$ a estos hijos mestizos les llama sobrinos y dizen que son hijos de sus ermanos y parientes. Y ancí rrecresen muchos pecados y se enseñan las yndias unos con otros. (p. 582)

Por último, se observa una correlación entre el pecado de la lujuria y el de la gula, tal como aparece ilustrado en diversas imágenes de la Nueva corónica (p. 548). Esta asociación parece derivar de la doctrina cristiana puesto que fray Luis de Granada ya planteaba lo siguiente:

El estómago y los miembros vergonzosos son vecinos y compañeros y los unos a los otros se ayudan y conforman en los vicios. De donde los hombres dados a vicios carnales comúnmente son comedores y bebedores, y así en banquetes y vestidos gastan todo cuanto tienen. (1950 [1567], p. 688)

El motivo de la mujer india violada por el cura doctrinero u otras figuras del varón colonizador se manifiesta decenas de veces en el texto de Guaman Poma 
y posee una naturaleza ambivalente pues existe — algunas o muchas veces - una corriente de deseo sexual entre ambos sujetos. Por un lado, las mujeres indias al ser violadas aparecen como víctimas pasivas de la lujuria o la potencia animal de la concupiscencia en términos cristianos medievales; sin embargo, no solo pierden su honra, sino que se transforman cualitativamente. La crónica insiste innumerables veces en que "se hacen putas y paren mesticillos", con lo cual un nivel de agencia y el deseo sexual se desplaza hacia ellas.

\section{Las indias putas o las tácticas sexuales de las mujeres colonizadas}

La figura de Mama Huaco ${ }^{9}$ y sus ambiguos recorridos narrativos ha sido motivo de varios estudios ${ }^{10}$. Ella inicia con Manco Capac la dinastía inca, definida por la idolatría y la pérdida de poder de los señores principales locales. No obstante, también revela el poder primordial de la mujer en el orden cósmico, una gran hechicera que instaura el reino del amaru, pues se constituye como mediadora entre las fuerzas subterráneas con el mundo de los hombres y el mundo celestial (Garcés, 1996, pp. 74-76). Además, su conducta sexual libre y desordenada configura adulterios e incesto, en palabras del cronista: "Dizen que se echaua con los hombres que ella quería de todo el pueblo" (p. 81). Por su parte, las mujeres indias del presente son simultáneamente víctimas del mal gobierno, pero también son agentes sexuales que expresan y reproducen mediante sus hijos mestizos el desorden y el caos del mundo colonial. Las mujeres indias del presente conservan el poder y la ambivalencia moral de Mama Huaco. En consecuencia, el personaje mítico, único e individualizado se actualiza en el presente de la escritura en esta figura colectiva y anónima: indias putas. Ellas convierten el tiempo ontológico del mito en la secuencia diacrónica del devenir histórico.

El deseo sexual y el poder colonial aparecen entonces como dos caras de la misma moneda en el texto: el corregidor, el encomendero, el cura doctrinero, todas las autoridades

[...] con poco temor de Dios y de la justicia y de la ley de cristiano, andan rrondando y mirando la güergüenza de las mugeres casados y donzellas y hombres prencipales. Y andan rrobando sus haziendas y fornican a las cazadas y a las donzellas los desuirga. (p. 508) 
Esta estructura sintáctica contiene una serie asombrosa: las autoridades españolas no solo roban y violan, sino que solazan su libido contemplando el órgano sexual de las mujeres y de los varones principales. Cabe recordar que estos últimos son aquellos que Guaman Poma presenta siempre vestidos aun en las más extremas circunstancias. De este modo, poder y sexo se enroscan en espirales que desbordan el deseo heterosexual.

El análisis de una de las imágenes más chocantes y perturbadoras en la Nueva corónica ratifica esta corriente de deseo sexual que se imbrica con el poder colonial. La imagen perturba por su crudeza ya que en ella dos varones destapan a una mujer india que duerme desnuda:

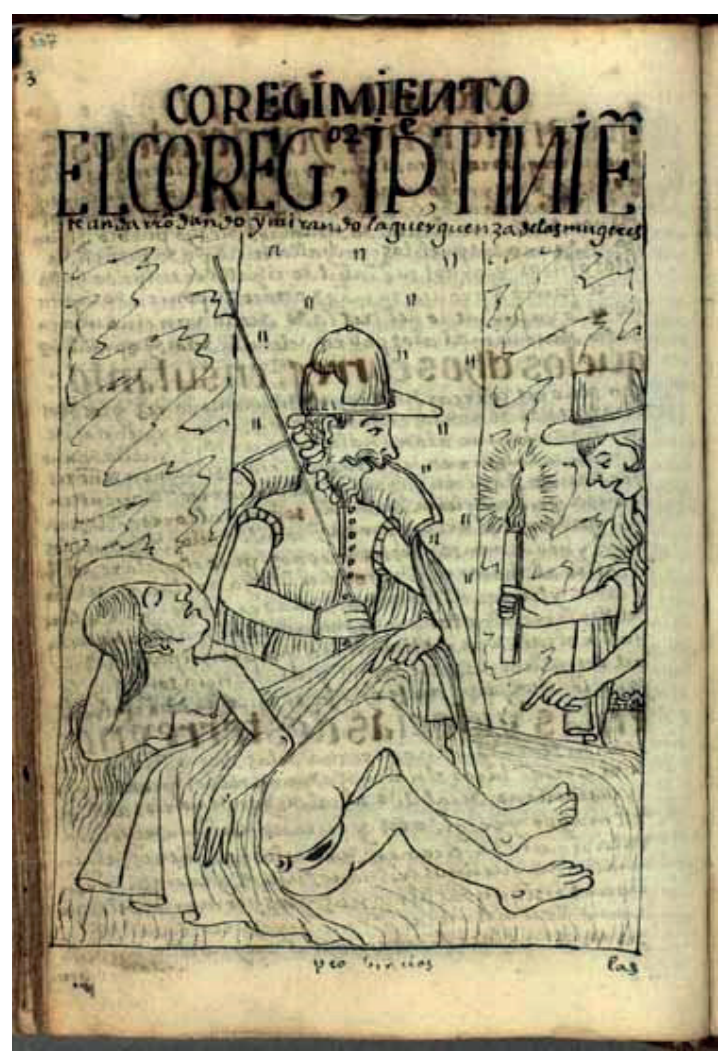

Figura 5. Nueva corónica y buen gobierno (1615), p. 507. Biblioteca Real de Copenhague, Dinamarca. 
Su cuerpo exhibe sus dos orificios sexuales abiertos y estos funcionan como los verdaderos ojos de ella (la poesía erótica popular tiene versos en los que traza esta asociación metafórica); es decir, la mujer está contemplando a los varones con los ojos que los someten. Además sus ojos del rostro están cerrados, pero su boca está entreabierta; si a ello le sumamos la posición del cuerpo, todo refiere a un claro mensaje sexual que ella activa y controla. Por otro lado, los dos varones (el corregidor español y el teniente indio) no se atreven a mirar directamente la vagina y el ano de la mujer; el segundo tiene los ojos cerrados y la vela que sostiene ilumina nuestro campo visual, pero no el del corregidor que mira hacia los ojos cerrados del ayudante. Este juego de miradas está poblado de veladuras: los varones no miran lo que desean; el que porta la luz, cierra los ojos y el otro busca en los ojos de su compañero el reflejo imposible de lo que no se atreve a mirar. En contraposición, el deseo sexual femenino sí los mira. Los varones señalan con el dedo índice extendido ${ }^{11}$ hacia esa zona del cuerpo femenino que fascina y espanta y, a pesar de que ambos portan signos fálicos (el cirio y la alabarda), no asumen un protagonismo semejante al del cuerpo desnudo de la mujer india. Este dibujo e innumerables pasajes del texto ratifican la acción de las mujeres indias y el valor de cambio que le asignaron a su sexualidad para obtener mejoras y ventajas en condiciones muy adversas. Las mujeres indias no fueron solo o siempre víctimas pasivas, sino que buscaron crear vínculos personales de dependencia con las figuras de poder para así obtener beneficios materiales. El texto lo expresa enfáticamente:

¿Por qué cauza quieren ser cocinera y chichera y panadera y lauandera y manseba y ciruiciales yndias de los dichos corregidores y padres de las dotrinas y comenderos y de jueses y becitadores? Con color de ella cada uno pide su mitayo y de comer cin costa. Y le haze trauajar a los pobres yndios y le rroba quanto puede y no ay rremedio. (p. 518)

Las indias aprovechan entonces el vínculo sexual que establecen con las figuras de gobierno para incorporarse a los eslabones de dominación local. En general, el contacto sexual interétnico con "español o mestizo o negro mulato" arrastra — según el texto- a estas mujeres indias a nuevos pecados y conductas transgresoras que las colocan fuera de servicio de las dos majestades y así las 
hacen equivalentes a sus propios agresores. El trato sexual las corrompe en todos los planos:

[...] estas dichas yndias salen enbusteras, bachelleras, ladronas, muy grandes putas, tanberas peresosas, amigas de comer, rregalos y ni cirue a Dios ni a su Magestad ni obedese a sus justicias ni a sus caciques prencipales ni a sus padres y madres ni a sus maridos. (p. 869)

La serie mezcla pecados con conductas sociales anómicas que destruyen la comunidad de indios y el núcleo familiar; destaca también el adjetivo "bachilleras" como término peyorativo, confluencia de la mirada patriarcal que asociaba escritura y sabiduría con el campo masculino y que desacreditaba la capacidad del saber oral popular. En síntesis, las mujeres andinas vivían en el pecado y fuera del orden social ideal de las dos repúblicas.

La consecuencia principal de esta transformación es que ellas ya no serán parte de la reproducción social de la población indígena ni podrán formar familias cristianas, pues según el autor andino: "ya no quiere casarse con yndio hatun luna, yndio uajo. Y estas yndias son peores que negras y no tienen ya honrra. Entrando una ues a casa del padre o de español, pierden la honrra hasta murir" (p. 869). La Nueva corónica y buen gobierno constata así, con dolor y rabia, que las mujeres indias prefieren compañeros sexuales del grupo de los españoles y, por ello, el agravio social las coloca simultáneamente en un doble lugar de lo abyecto: en el lugar más bajo de la escala social, debajo de la mujer esclava, y en el reino del pecado, pues carecen de honra, virtud suprema y se alejan constantemente del ideal de la mujer cristiana.

\section{Reflexión final}

Los tópicos narrativos signados por la soberbia y la lujuria, junto con las complejas relaciones sociales entre las figuras de poder y los indios, representados con crudeza y profundidad en la Nueva corónica y buen gobierno, han seguido poblando la literatura latinoamericana siglos después de haber sido escrita $^{12}$. La estrategia cognitiva transcultural del texto y sus múltiples lugares de enunciación permiten una representación densa y simbólica, mediante narraciones 
e ilustraciones visuales de la violencia colonial aleatoria e inmotivada y de las diversas estrategias de resistencia de los indios (desde la lectoescritura hasta la seducción sexual). Guaman Poma condena en términos morales cristianos, políticos cortesanos y económicos andinos esta violencia múltiple. Las diversas narraciones sobre la trayectoria de Toledo y el dibujo de su muerte posibilitan que se formalice una expresiva amenaza retórica contra las figuras del mal gobierno: corregidores, encomenderos y curas doctrineros que por su soberbia actúan despóticamente contra los indios enfrentarán este final de vida.

Por último, la representación del cuerpo indio como territorio de castigo y como espacio de goce sexual para las autoridades españolas revela las complejas redes e imbricaciones entre poder y sexualidad. El autor denuncia que mediante esta doble violencia los españoles trataban a los indios como si fuesen esclavos: varones que pueden ser castigados sin límite o mujeres cuyo cuerpo es propiedad sexual del amo y, por eso, carecen de honra. En esta dinámica, el papel del cura doctrinero adquirió particular relevancia por su violencia física contra los indios y el acceso sexual privilegiado que en la práctica mantuvo con mujeres indias jóvenes.

En suma, el binomio curas violadores/indias putas constituye la máxima expresión del "mundo al revés" en los Andes coloniales porque anuncia la inversión de los valores cristianos, el fracaso del proyecto evangelizador y la imposibilidad de reproducción del mundo social andino. Sin embargo, las narraciones y los dibujos de la Nueva corónica y buen gobierno revelan —en contra del deseo del propio autor- que las mujeres indias se instauraron como agentes que empleaban libremente su sexualidad para sobrevivir y engarzarse con las figuras del poder colonial y, por ello, inscriben su conducta en el ambivalente paradigma de Mama Huaco.

\section{Notas}

1 Todas las citas del texto provienen de la edición digitalizada del manuscrito que se encuentra disponible en el portal de red de la Biblioteca Real de Copenhague (Guaman Poma, 2001 [1615]). Anoto aquí la numeración corregida de las páginas en esta edición. 
2 Este es el nombre genérico con que Guaman Poma denomina a diversos auquénidos (llama, alpaca, vicuña y guanaco) propios del mundo andino, y fundamentales para la textilería y el comercio. La llama y la alpaca eran/son domesticados, mientras que la vicuña y el guanaco eran animales salvajes.

3 Aunque de forma indirecta, con este razonamiento se condena también la decapitación de Atahualpa ordenada por Pizarro cuarenta años antes y se ratifica la translatio imperii de Huáscar al rey de España, como lo narra el cronista.

4 "Que las dichas yndias en este rreyno biudas y solteras y niñas, biejas no an de texer rropa de la taza ni hilallo ni torser ni para comendero, corregidor, padre ni para tiniente, mayordomo, españoles ni para otro nenguno ci no fuere para la comunidad y sapci, conforme la ley y horden antigua que an tenido desde los Yngas y como lo tiene mandado el señor don Francisco de Toledo en sus hordenansas y confirmado de su Magestad" (p. 910). Respecto del sistema de irrigación, las normas provienen de los primeros reyes y señores de los reinos, han sido respetadas por los incas y guardadas por el propio Toledo (p. 958).

5 "Que para quitar la borrachera a los yndios y comer coca, no hallo otro rremedio, penas ni castigos. No hazen caso; aunque el señor don Francisco de Toledo, bizorrey, dejó medida para que beuan la chicha los yndios en la hordenansa, no abido rremedio" (p. 877).

6 En los dibujos de Guaman Poma, los dos incas ajusticiados, Atahuallpa y Tupac Amaru, son decapitados (pp. 390 [392]; 451 [453]).

7 Un análisis clave sobre esta relación entre escritura y mundo andino en la crónica de Guaman Poma se puede leer en el cap. IV del libro de Quispe-Agnoli (2006).

8 El Lazarillo de Tormes es el ejemplo por excelencia.

9 Su iconografía es transcultural y posee rasgos que forman parte de los grabados de la cultura visual del Medioevo y el Renacimiento que circularon en tierras americanas. Los especialistas han identificado la misma posición de la denominada "Reina de las Flores" y el atributo del espejo que también se repite como un emblema de la vanagloria de la vanidad (De Guchte, 1992, p. 107). Para una lectura más amplia sobre las tradiciones artísticas europeas y su influencia en la Nueva corónica, puede consultarse Holland (2008).

10 Un trabajo pionero fue el artículo de Rolena Adorno del año 1979, incluido posteriormente como capítulo quinto de su Cronista y príncipe (1992). Un recuento de los principales argumentos y una interesante lectura comparativa con el tratamiento de este personaje en la obra del Inca Garcilaso de la Vega puede consultarse en Vicuña Guengerich (2013).

11 Mercedes López-Baralt ha identificado en la representación desnuda del sexo una de las "estridencias más chocantes en el texto visual de Guaman Poma [...] y una señalización sexual muy importante en los dibujos que tienen figuras vestidas" (1993, pp. 109-110). Habría que añadir que ese mismo dedo que señala al sexo 
es el que encarna y simboliza la autoridad del poder colonial en otras muchas ocasiones.

$12 \mathrm{La}$ centralidad del cuerpo indígena lacerado, golpeado, despojado y humillado constituye una comprehensión cabal de la maquinaria colonialista y poscolonialista que configura uno de los ejes centrales de la novela indigenista. Paralelamente, el motivo de la mujer indígena violada por el cura se prolonga en dichas novelas y otras que buscaron la representación del indio desde códigos románticos, realistas, naturalistas y neorrealistas desde el siglo XIX. Estos motivos narrativos suelen tener gran relevancia en la trama, como lo prueban las novelas Aves sin nido (1889), Wuata Wuara (1905), Huasipungo (1934) y El mundo es ancho y ajeno (1941).

\section{Referencias bibliográficas}

Adorno, R. (1992 [1989]). Cronista y príncipe: la obra de don Felipe Guaman Poma de Ayala. Lima: Fondo Editorial de la Pontificia Universidad Católica del Perú.

De Guchte, M. Van. (1992). Invention and assimilation. European engravings as models for the drawings of Felipe Guaman Poma de Ayala. En R. Adorno (Ed.), Guaman Poma de Ayala. The Colonial Art of an Andean Author (pp. 92-109). Nueva York: Americas Society.

Elias, N. (1996 [1969]). La sociedad cortesana. Ciudad de México: Fondo de Cultura Económica.

Garcés, M. A. (1996). Fundaciones míticas: el cuerpo del deseo en Waman Puma. En M. Moraña (Ed.), Mujer y cultura en la colonia hispanoamericana (pp. 67-87). Pittsburgh: Biblioteca Americana.

Granada, F. L. de. (1950 [1567]). Guía de pecadores. Madrid: Aguilar.

Guaman Poma de Ayala, F. (1980 [1615]). Nueva corónica y buen gobierno. Edición de R. Adorno, J. Murra y G. Urioste. Madrid: Siglo XXI.

Guaman Poma de Ayala, F. (2001 [1615]). El sitio de Guaman Poma. Nueva corónica y buen gobierno. Copenhague: Biblioteca Real. Recuperado de http://www.kb.dk/permalink/2006/poma/info/en/frontpage.htm

Holland, A. E. (2008). Nueva corónica: Tradiciones artísticas europeas en el virreynato del Perú. Cuzco: Centro de Estudios Regionales Andinos Bartolomé de Las Casas. 
López-Baralt, M. (1993). Guaman Poma, autor y artista. Lima: Fondo Editorial de la Pontificia Universidad Católica del Perú.

Quispe-Agnoli, R. (2006). La fe andina en la escritura: resistencia e identidad en la obra de Guamán Poma de Ayala. Lima: Fondo Editorial de la Universidad Nacional Mayor de San Marcos.

Vicuña Guengerich, S. (2013). Virtuosas o corruptas: las mujeres indígenas en las obras de Guamán Poma y Garcilaso de la Vega. Hispania, 96(4), 672673. doi: 10.1353/hpn.2013.0109 